\title{
WHITE-EYED VIREO IN REGINA - FIRST FOR SASKATCHEWAN
}

FRANK H. BRAZIER, 2657 Cameron Street, Regina, Saskatchewan. S4T 2W5

Shortly before noon on 19 May 1988 a small bird flew into the rowan tree growing on the south side of the lawn at 2657 Cameron Street in Regina. It was about $28 \mathrm{~m}$ away, on an outside branch half way up, in clear view. The prominent white eye, two conspicuous white wing bars, white edging to the secondaries and primaries and yellow side identified the bird as a White-eyed Vireo which I had seen some years before in Louisiana.

1 managed a brief look with binoculars, enough to note the field marks. The bird was in profile so that the "spectacles" could not be seen, but I could see the eye-ring and a very short projection that was the beginning of the forehead bar. The white iris and vireo bill were clearly seen. The bird flew off shortly, so that I could not make a prolonged study.

The White-eyed Vireo is a rare bird in Canada. Godfrey states that it nests rarely and locally in southern Ontario. He lists photo records for Nova Scotia and Quebec and a sight record for Winnipeg on 3 and 4 July 1981 . $^{6}$ Bennett reports the first sighting for the Rimouski, Quebec area on 22 June 1987, and that they "... were easy to find" at Point
Pelee, Ontario on 14 May 1988 Cleveland et al do not mention it southeastern Manitoba where lí numbers of species seen are consist ly recorded. ${ }^{5}$ Berkey reports banded on 20 May 1982 for the seve South Dakota sighting and a sightin Sioux Falls on 8 May 1987 is noter "... a rare record for South Dakota North Dakota appears to have records.

This sighting constitutes an addit to the hypothetical list of Saskatche birds.

1 BENNETT, G. 1988. Birdfinding Canada 8(2):16.

2 BENNETT, G. 1988. Birdfinding Canada 8(4):21.

3 BERKEY, G.B. 1982. Northern Plains. Am. Birds 36(5):867.

4 BERKEY, G.B. 1987. Northern Plains. Am. Birds 41(3):454.

${ }^{5}$ CLEVELAND, N.J.*** 1980. Bir guide to southeastern Manitoba. Series No. 1. Winnipeg: Man. Nat. Sc

6 GODFREY, W.E. 1986. The bird Canada, revised edition. Ottawa: Nati Mus. of Can. 